\title{
Investigating the Influence of Heavy Oil Recovery by In Situ Combustion during Air Injection as EOR Technique
}

\author{
a,b* Azizullah Shaikh, ${ }^{\mathrm{c}}$ Tunio Abdul Haque, ${ }^{\mathrm{b}}$ Caili Dai, ${ }^{\mathrm{b}}$ Yongpeng Sun, ${ }^{\mathrm{b}}$ Guang Zhao, ${ }^{\mathrm{a}, \mathrm{b}}$ Allah \\ Bakhsh, ${ }^{a}$ Ahmer Hussain Shah, ${ }^{\text {b,c }}$ Ubedullah Ansari, \\ a: Balochistan University of Information Technology, Engineering and Management Sciences, Quetta \\ 87300, Pakistan \\ b: School of Petroleum Engineering; China University of Petroleum (East China), Qingdao-China \\ c: Institute of Petroleum and Natural Gas Engineering; Mehran University of Engineering and \\ Technology Jamshoro, Sind-Pakistan \\ *Corresponding author Tel.: +92-3333518081 \\ E-mail: hafiz_aziz@yahoo.com, hafiz.azizullah@buitms.edu.pk
}

\begin{abstract}
Heavy oil is one of the most useful energy resources specially in the times of crises when other resources are not present in profusion. However, Occurrence of heavy oil in unconsolidated sands is one the most challenging factor to recover the heavy oil. Therefore, in this study the main focus is derived towards the extraction of heavy oil with optimistic procedure called air injection. For the research, a reactor assembly was developed for the experimental work on air (21\% oxygen) injection into heavy oil (12.59 $\left.{ }^{\circ} \mathrm{API}\right)$ reservoir. Total 13 kinetics runs were conducted on unconsolidated cores by varying the parameters involved system pressure, flow rate (air flux), oxidation temperature (heat input), and rock formation (sand matrix). It was found that the process is very dependent on operating conditions employed, as oxygen consumption rate was very dependent on air flux. Increase of air flux from 15.19 to 22.78 $\mathbf{m}^{3} / \mathbf{m}^{2}-\mathbf{h r}$ resulted in slightly increasing rates of oxygen consumption over the temperature range under investigation. The temperature difference also shows great effect on the high temperature oxidation. The pressure and porous media also have great impact on the combustion behavior. The influence of individual parameter was obtained from analysis of the inlet oxygen and composition of flue gases from the combustion cell. Indeed, the oxygen conversion was too less to evaluate the kinetic data at temperature less than $250{ }^{\circ} \mathrm{C}$ while for oxidation reactions, the oxygen statistics analyzed from temperature above than $350{ }^{\circ} \mathrm{C}$. The experimental results reveal that the average maximum peak temperature was $440{ }^{\circ} \mathrm{C}$, and the oxidation reaction process at high temperature was very effective in terms of produced carbon oxides with an average percentage of $9.5 \% \mathrm{CO}_{2}, 5.5 \% \mathrm{CO}$ in flue gases. Oil displacement was observed from the analysis of flue gases, consequently; incremental oil recovery was achieved between $56 \%-80 \%$ under high temperature oxidation (HTO) conditions.
\end{abstract}

Keywords- Air Injection; Enhanced Oil Recovery; Heavy Oil; High Temperature Oxidation; Oxidation Reaction

Date Received 16 Apr 2020

Date Accepted 15 June 2020

Date Published 25 June 220

\section{INTRODUCTION}

Petroleum incorporates one of the major sources of energy in the world and approximately $67 \%$ of the world's energy comes from oil and natural gas [1]. Generally, it is accepted that almost two-third of the original oil-in-place (OOIP) rests in the subsurface reservoirs following by primary and secondary recovery techniques. During the last decades it is believed that due to decline in oil discoveries, EOR technologies will perform a significant part in years to come to acquire the energy demand [2]. EOR methods have been widely applied for improving oil production from light oil $\left(>32^{\circ} \mathrm{API}\right)$, medium oil

Journal of Applied and Emerging Sciences Vol (10), Issue (01) $\left(22^{\circ}-32^{\circ} \mathrm{API}\right)$, heavy oil $\left(10^{\circ}-22^{\circ} \mathrm{API}\right)$, and extra heavy/tar sands $\left(<6^{\circ} \mathrm{API}\right)$ reservoirs with the aim of achieving economic oil production $[2,3]$.

Generally, EOR techniques are classified as thermal and nonthermal methods. The selection of the method is frequently dependent over the reservoir fluids, formation characteristics, reservoir area and awareness from the same reservoirs. For medium/heavy oils and tar sands, thermal methods are mostly proposed, even they are appropriate to light oils in particular conditions. For light oils, non-thermal processes are usually applied but rarely, these methods for heavy oils have been tested with limited success in the field. Various challenges offered by heavy oil recovery are much more convoluted to recover from the reservoirs than medium and light oil.

Heavy oil occurs mostly in poorly consolidated sands with permeability of few darcies, and porosity in excess of $30 \%$. Usually, heavy oil is deposited at shallow (relatively low 


\section{DOI: https://doi.org/10.36785/BUITEMS.JAES.375}

pressure) formations. The primary and secondary recovery of heavy oil is small due to low mobility. In the situation of a typical $22^{\circ}$ API heavy oil, the primary recovery would be 5-15 percent, which may be improved to about 20 percent by secondary recovery [4]. Enhanced Oil Recovery aims to enhance the heavy oil left by natural displacement and secondary recovery.

In the early 1900s, an unintentional discovery of air injection (or oxygen-enriched air) was existed and introduced into an oil reservoir. While, it has been aggressively, successfully and profitably advanced as a thermal process for heavy oils in the 1960s and afterwards [5]. Air injection (also identified as insitu combustion or fire flooding) is getting bigger attention because of its great recovery potential and applicability to a broad variety of reservoirs. Air injection idyllically takes place between two vertical wells. During injection process, the flue gases and steam are formed when injected oxygen is intended to react with 5 to $10 \%$ of the residual oil-in-place [4] at peak temperature. The oil is ignited 'in situ' at/or close to the injection wellbore by down hole burners, electric heaters, steam or hot fluid injection and chemical agents. Oil is moved towards the producing wells by the direct action of the resultant thermal front, brought by the combustion gases, hot water and steam. The significance of each driving mechanism depends on the oil reservoir. The following supplements are mentioned in favor of the air injection process, acquired from the successful field applications to date.

- Thermally, air injection is the most efficient and very competent recovery process.

- Being a universally abundant, air is accessible as an inexpensive injection fluid, also it does not cause any restriction in supply.

- This technique is well recognized and proven in dissimilar reservoir settings i.e., shallow heavy oil and deep light oil reservoirs.

- The process can be efficient and applied in the cases where water flooding, steam flooding, $\mathrm{CO}_{2}$ flooding and chemical flooding are not efficient [5].

- In air injection process, improved production procedures and equipment are involved, as the existing infrastructure can often be employed.

- Due to air compressibility, the process occupies quicker re-pressurization than of water [5].

- The mechanism has superior access to the reservoir with horizontal wells $[5,6]$.

- Air injection process has substantial cost benefits as a substitute to other gases, such as; carbon dioxide $\left(\mathrm{CO}_{2}\right)$, hydrocarbon (HC) gas and nitrogen $\left(\mathrm{N}_{2}\right)$ [7].

- It also occupies the technological and economic achievement in the entire projects to date.

- One of the most significant and vital benefit of an air injection process is that it holds high displacement efficiency, and also does not need water as a mobility control agent $[8,9]$.

To design a successful and commercial air injection scheme in a heavy oil or bitumen reservoir, "Oxidation reaction" and "bulldozing effect" are two fundamental mechanisms, each of Journal of Applied and Emerging Sciences Vol (10), Issue (01) them must be understood by anyone. For oxidation reaction, two basic reaction modes related to the air injection technique in low gravity crude oils are namely 'oxygen addition' reactions and 'bond scission' reactions $[4,5,7]$, as mentioned in following forms.

\section{Oxygen addition reaction:}

$\mathrm{CH}_{\mathrm{x}}+\mathrm{O}_{2} \rightarrow \mathrm{CH}_{\mathrm{x}} \mathrm{O}_{\mathrm{y}}$ (Hydrocarbon + Oxygen $\rightarrow$ Oxygenated Compounds + Energy)

\section{Bond scission reaction:}

$\mathrm{CH}_{\mathrm{x}}+\mathrm{O}_{2} \rightarrow \mathrm{CO}_{\mathrm{x}}+\mathrm{H}_{2} \mathrm{O}$ (Hydrocarbon + Oxygen $\rightarrow$ Carbon oxides + Water + Energy)

It is essential to know the oxidation behavior of the crude oil for understanding and recognizing the viability of its application to a certain reservoir. Therefore, prior to the implementation of any field application, prevalent laboratory investigations are mandatory to determine reaction characteristics of the specific crude oil. Tunio A.H (2008) and Chandra Das (2009) conducted their thesis work on air injection process. The aim of the research was to achieve the oxidation reaction kinetics during air injection process applicable to a specified reservoir. To know the oxidation mechanism and to analyze and differentiate among the oxidation reactions obtained due to the combustion by using air injection, a series of thermal experiments was conducted to explore and examine the oxidation behavior of particular reservoirs in both air and oxygen environments.

For bulldozing effect, the major motive is that the combustion front performs as a bulldozer to mobilize high amount of the oil instantly in front of it, which could not be formerly displaced by the other performing driving mechanisms i.e. hot water/steam displacement and flue gas sweeping etc., this phenomenon is called 'bulldozing' effect of the combustion front. Ursenbach et al (2010) and Bagci (2007) carried out their research on an air injection in heavy oil reservoirs where they investigated that the air injection process is enhanced by improving of oil mobility and permitting strong displacement to the producing wells. The 'bulldozing' effect can possess troubles if not handled properly for the case of heavy oil and bitumen reservoirs, which are typically well saturated with oil. Hence this study is decisive solution to the procedural queries that are integrated with application of in situ combustion technique during air injection in order to enhance the recovery of heavy oil. Moreover, the unique approach of experimentally investigating the high temperature oxidation uplifts the applicability of outcomes from this research.

Economically, oil can be recovered by air injection process from a variety of reservoir situations, such as heavy oil (10-22 $\left.{ }^{\circ} \mathrm{API}\right)$ from thin/shallow reservoirs (lesser than 1500 feet) and light oil (greater than $32^{\circ} \mathrm{API}$ ) from deep reservoirs $(10,000$ feet) $[4,10]$. As compare to other gas injectants such as; $\mathrm{CO}_{2}$, $\mathrm{HC}$ gas and $\mathrm{N}_{2}$, air injection as an EOR process has large cost benefits $[7,11]$. 


\section{Methodology}

\section{A. Equipment}

An experimental set-up facility with different accessories was developed to understand the process of air injection into heavy oil reservoirs. The name of the apparatus with the abbreviation used in the experiments is listed in the tabular form, as shown in table 1 .

TABLE I

List of the apparatus with their abbreviations used in the experiments

\begin{tabular}{l|c}
\hline \multicolumn{1}{c|}{ Name of the apparatus } & Abbreviation \\
\hline Swagelok Fittings & SF \\
\hline Needle Valve & NV \\
\hline Flow Control Valve & FCV \\
\hline Vertical Reactor Assembly & VRA \\
\hline High Pressure Autoclave & HPA \\
\hline Combustion Cell & CC \\
\hline Reactor Heating System & RHS \\
\hline On/Off Relay & R \\
\hline Pressure Transducer & PT \\
\hline Electric Heater & EH \\
\hline Temperature Processor Controller & PID \\
\hline Six-Pen Paperless Recorder & RE \\
\hline Temperature Indicator & TI \\
\hline Thermocouples & T \\
\hline Dryer with Silica Gel & D \\
\hline Scrubber & S \\
\hline High Pressure Separator & HPsep \\
\hline Low Pressure Separator & LPsep \\
\hline Glass Tubes & GT \\
\hline Hydrogen Generator & HG \\
\hline Pressure Indicator & PI \\
\hline Air Compressor for Hydrogen Generator & AC \\
\hline Flow Metering System & FM \\
\hline Back-Pressure Regulator & BPR \\
\hline High Pressure Air Cylinder & AC \\
\hline Gas Sampling Point & GSP \\
\hline Nitrogen Cylinder & NS \\
\hline Gas Sampling System & GSS \\
\hline Gas Chromatograph & RC \\
\hline Chromatocorder-12 & TGS \\
\hline Tight Gas Syringe & C \\
\hline Cylinder & \\
\hline &
\end{tabular}

The arrangement of all the above accessories is shown in a simplified schematic diagram of the air injection apparatus in figure 1 .

Journal of Applied and Emerging Sciences Vol (10), Issue (01)

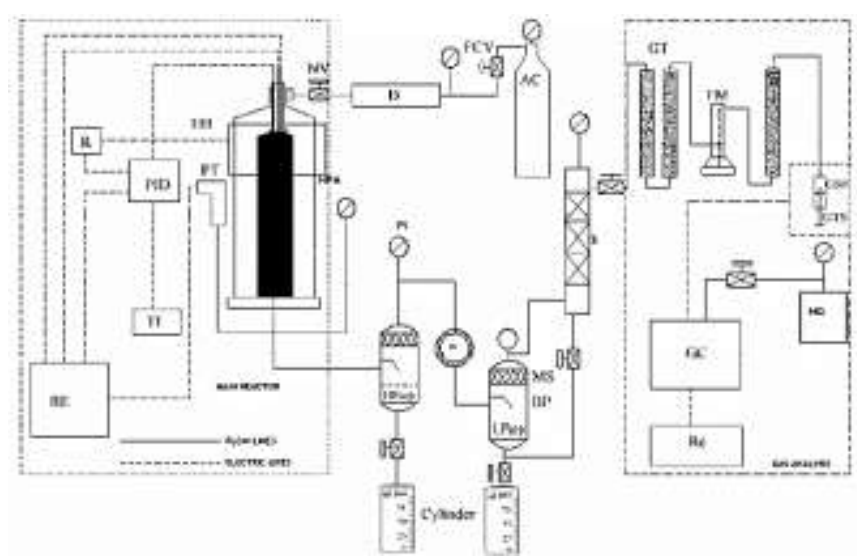

Fig. 1. Schematic diagram of air injection apparatus

\section{B. Preparations for Experimental Work}

The experiments were conducted with a mixture of sand (unconsolidated rock sample) and heavy crude oil. The sand and the required amount of heavy crude oil were mixed, and then blended with the help of spatula until it became homogenous. Afterwards, the mixture of loose (unconsolidated) sand equal to the weight of the original consolidated core was put into the combustion cell to its full length. After that to achieve the composition of sand pack components similar to reservoir conditions, a uniform pressure was applied to the combustion cell. Table 2 shows the summary of combustion cell with oil sand pack properties.

TABLE II

Properties of heavy crude oil and sand pack with combustion cell

\begin{tabular}{l|c|l|c}
\hline \multicolumn{2}{c|}{$\begin{array}{c}\text { Crude oil } \\
\text { properties }\end{array}$} & \multicolumn{2}{c}{$\begin{array}{c}\text { Combustion cell and sand } \\
\text { pack properties }\end{array}$} \\
\hline $\begin{array}{l}\text { Oil } \\
\text { gravity }\end{array}$ & $\begin{array}{c}12.59^{\circ} \\
\text { API }\end{array}$ & $\begin{array}{l}\text { Combustion cell } \\
\text { length }\end{array}$ & $25.4 \mathrm{~cm}$ \\
\hline $\begin{array}{l}\text { Specific } \\
\text { gravity }\end{array}$ & 0.982 & $\begin{array}{l}\text { Combustion cell } \\
\text { radius }\end{array}$ & $\begin{array}{c}1.5875 \\
\mathrm{~cm}\end{array}$ \\
\hline $\begin{array}{l}\text { Viscosity } \\
\text { at } 100^{\circ} \mathrm{F}\end{array}$ & $\begin{array}{c}3726 \\
\mathrm{cp}\end{array}$ & $\begin{array}{l}\text { Combustion cell } \\
\text { bulk volume }\end{array}$ & $201 \mathrm{~cm}^{3}$ \\
\hline $\begin{array}{l}\text { Carbon } \\
\text { weight }\end{array}$ & $87.4 \%$ & Sand pack length & $24.1 \mathrm{~cm}$ \\
\hline $\begin{array}{l}\text { Hydroge } \\
\mathrm{n} \text { weight }\end{array}$ & $10.9 \%$ & Porosity & $36 \%$ \\
\hline $\begin{array}{l}\text { Sulphur } \\
\text { weight }\end{array}$ & $0.9 \%$ & Permeability & $\begin{array}{c}1.273 \\
\text { darcy }\end{array}$ \\
\hline Others & $0.8 \%$ & $\begin{array}{l}\text { Sand weight in the } \\
\text { cell }\end{array}$ & \begin{tabular}{c}
$200 \mathrm{gms}$ \\
\hline
\end{tabular} \\
\hline
\end{tabular}

Then combustion tube was placed centrally in the pressure 


\section{DOI: https://doi.org/10.36785/BUITEMS.JAES.375}

cell. In order to diminish the heat losses and to inhibit premature cracking reactions with oil in the sand pack, the annular space $\mathrm{b} / \mathrm{w}$ combustion tube and pressure cell was insulated by filling the clean sand. The bottom flange assembly of combustion cell was bolted with the flange of pressure shell. The high-pressure cell placed on rack and connected with inlet and outlet connections by using of swagelok fittings. Three heaters were wrapped around the pressure autoclave to meet a nearby adiabatic condition for the combustion tube and also three thermocouples were inserted to the combustion tube to track the combustion front propagation. The reactor was pressurized to the required pressure of experiment and held constant by isolating for 30 minutes. With no decline in pressure, the experiment was then commenced.

\section{Calibration of Alltech Dual Concentric Column}

A dual concentric column (Alltech CTR1\# 8700) was comprised on the inner packed tube (6ft length and 0.125 inch inner diameter) and outer packed tube (6ft length and $0.25 \mathrm{inch}$ inner diameter). The inner packed tube was filled with a porous polymer mixture, while the outer packed tube was filled with activated molecular sieve for the analysis of $\mathrm{CO}_{2}, \mathrm{CO}, \mathrm{O}_{2}, \mathrm{~N}_{2}$, and $\mathrm{CH}_{4}$ under non isothermal conditions.

The column was calibrated with specified calibration gas mixture (Alltech \# 9799) recommended for the CTR1 column, as shown in figure 2. This column is useful for the analysis of effluent gases during combustion. The all experiments were conducted using this column and according to the composition of the gas calibrated by the column, as shown in table 3 .
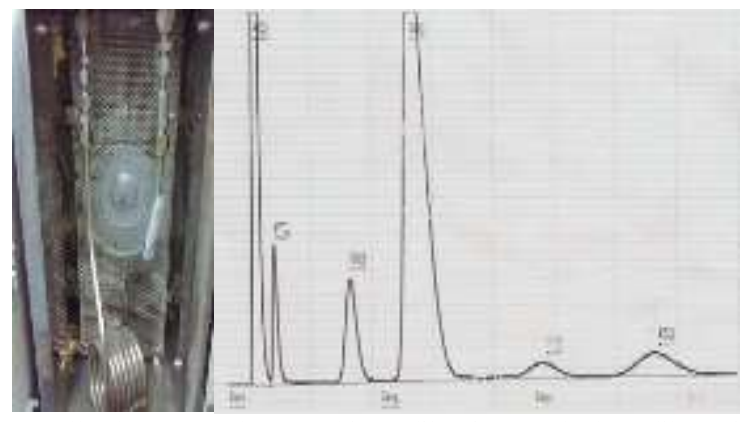

Fig. 2. Alltech CTR1 column and its Calibration results by calibrated gas mixture

TABLE III

Composition of the gas, calibrated by the column (Alltech CTR1\# 8700)

\begin{tabular}{c|c|c|c|c}
\hline NO: & Name & $\begin{array}{c}\text { Retention } \\
\text { time }\end{array}$ & A or H & $\begin{array}{c}\text { Concent- } \\
\text { ration, \% }\end{array}$ \\
\hline 1 & $\begin{array}{c}\text { Comp- } \\
\text { osite }\end{array}$ & 0.454 & 374476 & 37.6333 \\
\hline 2 & $\mathrm{CO}_{2}$ & 0.774 & 36560 & 3.0674 \\
\hline 3 & $\mathrm{O}_{2}$ & 2.018 & 58707 & 5.8998 \\
\hline 4 & $\mathrm{~N}_{2}$ & 3.008 & 459188 & 46.1465 \\
\hline
\end{tabular}

Journal of Applied and Emerging Sciences Vol (10), Issue (01)

\begin{tabular}{|c|c|c|c|c|}
\hline 5 & $\mathrm{CH}_{4}$ & 5.192 & 22182 & 2.2292 \\
\hline \multirow[t]{2}{*}{6} & $\mathrm{CO}$ & 7.039 & 43952 & 4.4169 \\
\hline & \multicolumn{2}{|c|}{ Total } & 995067 & 100.0000 \\
\hline
\end{tabular}

\section{Experimental Procedure}

Figure 1 displays a schematic diagram of the principal equipment used to facilitate the air injection experiments on heavy oil reservoirs. The procedure of all combustion tube runs (experiments) have been carried out according to the following order.

i. For removing water vapors present in the effluent gas stream, the air at pressure of 2069 to $4827 \mathrm{KPa}$ with drawn through dryer, combustion cell, high pressure separator, low pressure separator, scrubber and series of three glass tubes filled with Silica gel.

ii. After 30 minutes, the air supply was delivered and controlled through cylinder regulator at high-pressure of $13652 \mathrm{KPa}$ by means of compressed synthetic air cylinder. The required pressure was maintained and stabilized.

iii. Pressure regulator was used to control the reactor pressure, which was installed at the outward stream of the high-pressure separator.

iv. The flow of produced gases was formed from outward stream of the regulator to the low-pressure separator, scrubber and to the sample collecting unit.

v. Air injection flow rate was regulated and controlled by needle valve/flow control valve, installed at the inlet of the reactor.

vi. With a ramp of $\left(5^{\circ} \mathrm{C} / \mathrm{min}\right)$, the reactor was heated for the period of experiments and held constant to $500{ }^{\circ} \mathrm{C}$ \pm 50 .

vii. To generate the ignition in the reactor, required airflow was reputed through the porous media (sand pack), the autoclave was heated up by one electric heater/igniter $(1.0 \mathrm{KW})$, which was wrapped around the top of the reactor. The ignition could be observed on the temperature recorder from the change of slope on the temperature versus time chart.

viii. After the ignition, the inlet gas stream from top of the reactor was permitted, while the combustion front formed by flue gases was flowing from igniter to the bottom of the combustion tube/reactor. Three thermocouples were used to measure the inside temperature at three different sections (upper, middle, and lower) of the reactor.

ix. Flue gas samples were collected with a tight gas syringe of $1.0 \mathrm{ml}$ capacity after every 10 minutes for the entire reaction time. For each oxidation run, the $\mathrm{CO}_{2}, \mathrm{CO}, \mathrm{O}_{2}$ and $\mathrm{N}_{2}$ concentration in the exhaust gas were determined as a function of time.

x. At the completion of the experiment, the crude oil recovery was obtained from the outlet of high-pressure and low-pressure separator. 


\section{RESULTS AND ANALYSIS}

The results and their analysis achieved from the various runs were based on useful kinetic data which was obtained from the effluent gas. Total 13 kinetic runs were performed by the use of air injection (in-situ combustion) method for the recovery of heavy crude oil $\left(12.59^{\circ} \mathrm{API}\right)$. The experiments were conducted by varying the parameters involved system pressure, flow rate (air flux), oxidation temperature (heat input), and rock formation (sand matrix). The influence of individual parameter was obtained from study of the inlet oxygen and composition of flue gases $\left(\mathrm{O}_{2}, \mathrm{CO}_{2}\right.$, and $\left.\mathrm{CO}\right)$ from the combustion cell.

\section{A. Pressure Effect on Heavy Oil Recovery}

For better analysis, air at four different pressures was injected for oxygen consumption with function of time as an abscissa. The figure 3 ( A, B, C, and D) indicates the amount of consumed oxygen at different pressures. The summary of the effect of different operating pressures on composition of the flue gases is mentioned in table 4 .

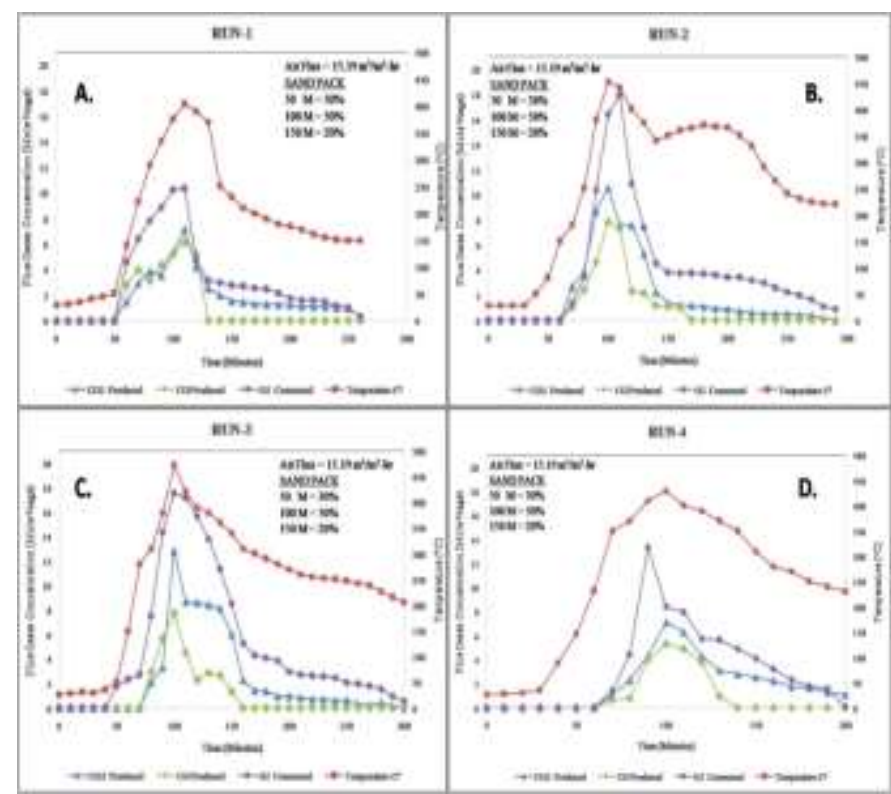

Fig. 3. Flue gases concentration and temperature versus time, A. at $9750 \mathrm{KPa}$ B. at $10900 \mathrm{KPa}, \mathrm{C}$. at $11700 \mathrm{KPa}$, and D. at $12850 \mathrm{KPa}$

TABLE IV

Summary of operating and control parameters by the effect of system pressure

\begin{tabular}{|c|c|c|c|c|c|c|}
\hline \multirow{2}{*}{$\begin{array}{l}\text { Run } \\
\text { No. }\end{array}$} & \multicolumn{2}{|c|}{$\begin{array}{c}\text { Injected } \\
\text { Gas } \\
\text { Analysis }\end{array}$} & \multirow{2}{*}{$\begin{array}{c}\text { Operating } \\
\text { Pressure, } \\
\text { KPa }\end{array}$} & \multirow{2}{*}{$\begin{array}{c}\text { Temp: } \\
\text { Condition, } \\
{ }^{\circ} \mathbf{C}\end{array}$} & \multirow{2}{*}{$\begin{array}{c}\text { Flow } \\
\text { Rate, } \\
\text { ml/min }\end{array}$} & \multirow[t]{2}{*}{$\begin{array}{l}\text { Air Flux, } \\
\mathrm{Sm}^{3} / \mathbf{m}^{2}-\mathrm{hr}\end{array}$} \\
\hline & $\mathbf{O}_{2}$ & $\mathbf{N}_{2}$ & & & & \\
\hline 1 & 21 & 79 & 9750 & $\begin{array}{c}\text { Non- } \\
\text { Isothermal } \\
\left(5^{\circ} \mathrm{C} / \mathrm{min} .\right) \\
2^{\text {nd }} \text { Heater } \\
\text { installed @ }\end{array}$ & 200 & 15.19 \\
\hline 2 & 21 & 79 & 10900 & $\begin{array}{l}120 \mathrm{v} \text { to } \\
\text { maintain } \\
\text { the } \\
\text { reservoir }\end{array}$ & 200 & 15.19 \\
\hline
\end{tabular}

Journal of Applied and Emerging Sciences Vol (10), Issue (01)

\begin{tabular}{|c|c|c|c|c|c|c|}
\hline 3 & 21 & 79 & 11700 & $\begin{array}{l}\text { Temp. }(100 \\
\left.{ }^{\circ} \mathrm{C}\right)\end{array}$ & 200 & 15.19 \\
\hline 4 & 21 & 79 & 12850 & & 200 & 15.19 \\
\hline
\end{tabular}

The figures and table show that the reaction rate has been dropped by raising the pressure up to $12850 \mathrm{KPa}$. While the pressures from 9750 to $10900 \mathrm{KPa}$ have an equal progress in reaction rate, however an identical behavior is almost from the pressures 10900 to $11700 \mathrm{KPa}$. From the similar plots of carbon dioxide and carbon monoxide as presented in the figures, it can be observed that there was very early production of carbon monoxide in the experiments performed up to pressure of 12850 $\mathrm{KPa}$. Whereas, the light components are silent at high pressure of $12850 \mathrm{KPa}$. By great number of moles existing in the reactor, there is dilution effect [12] hence, produced the small level of products by increasing the pressure of $12850 \mathrm{KPa}$ in experiment. From the results, it is concluded that the products distribution is insufficient and does not act ideally.

Figure 4 shows that the final oil recovery was improved about $23.25 \%$, as the pressure was increased from 9750 to $10900 \mathrm{KPa}$. Also, no any major effect was detected when the pressure amplified up to $12850 \mathrm{KPa}$. The summary of main results obtained from these experiments is given in table 5 .

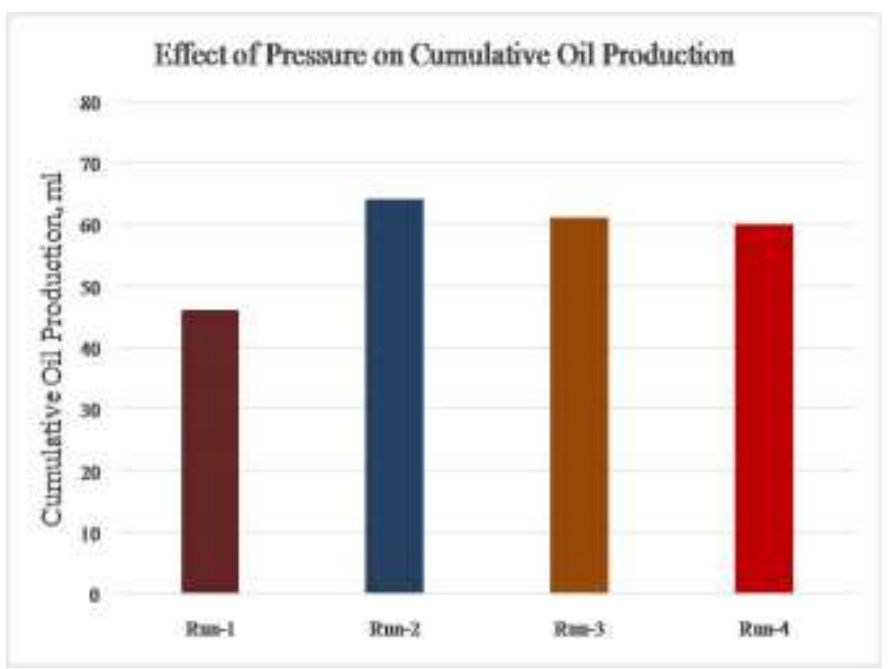

Fig. 4. Cumulative oil production at different pressures

TABLE V

Summary of combustion cell results by the effect of system pressure

\begin{tabular}{l|c|c|c|c}
\multicolumn{1}{c|}{ Parameters } & R-1 & R-2 & R-3 & R-4 \\
\hline Run Duration, Minutes & 260 & 290 & 300 & 200 \\
\hline $\begin{array}{l}\text { Cumulative Oil } \\
\text { Production, ml }\end{array}$ & 46 & 64 & 61 & 60 \\
\hline $\begin{array}{l}\text { Final Oil Recovery, \% } \\
\text { OOIP }\end{array}$ & 56.75 & 80.0 & 76.25 & 75.0 \\
\hline
\end{tabular}


DOI: https://doi.org/10.36785/BUITEMS.JAES.375

\begin{tabular}{l|c|c|c|c}
\hline $\begin{array}{l}\text { Combustion Front Peak } \\
\text { Temp., }{ }^{\circ} \mathrm{C}\end{array}$ & 403 & 453 & 472 & 430 \\
\hline $\begin{array}{l}\text { Max. Concentration of } \\
\text { Produced } \mathrm{CO}_{2}, \text { Mole \% }\end{array}$ & 7.1568 & 10.5780 & 12.8413 & 7.1291 \\
\hline $\begin{array}{l}\text { Max. Concentration of } \\
\text { Produced CO, Mole \% }\end{array}$ & 6.1486 & 7.8732 & 7.7843 & 5.3210 \\
\hline $\begin{array}{l}\text { Max. Concentration of } \\
\text { Consumed } \mathrm{O}_{2}, \text { Mole \% }\end{array}$ & 10.3161 & 17.9567 & 17.5781 & 18.4356 \\
\hline Utilization of $\mathrm{O}_{2}, \%$ & 49.1242 & 85.509 & 83.705 & 87.788 \\
\hline
\end{tabular}

\section{B. Air flux Effect on Heavy Oil Recovery}

Three different air fluxes (airflow rates per unit area of the reacting bed) of $15.19,19.02$ and $22.78 \mathrm{~m}^{3} / \mathrm{m}^{2}$-hr were used to examine the oxidation effect of heavy crude oil. Experiments were conducted on unconsolidated core at pressure of 13500 $\mathrm{KPa}$ with a temperature ramp of $5^{\circ} \mathrm{C}$ as presented in figure 5 $(\mathrm{A}, \mathrm{B}, \mathrm{C}$, and $\mathrm{D})$. The operating and control parameters are given in table 6. For better analysis, different air fluxes (flow rates) were drawn for oxygen consumption with function of time as an abscissa.

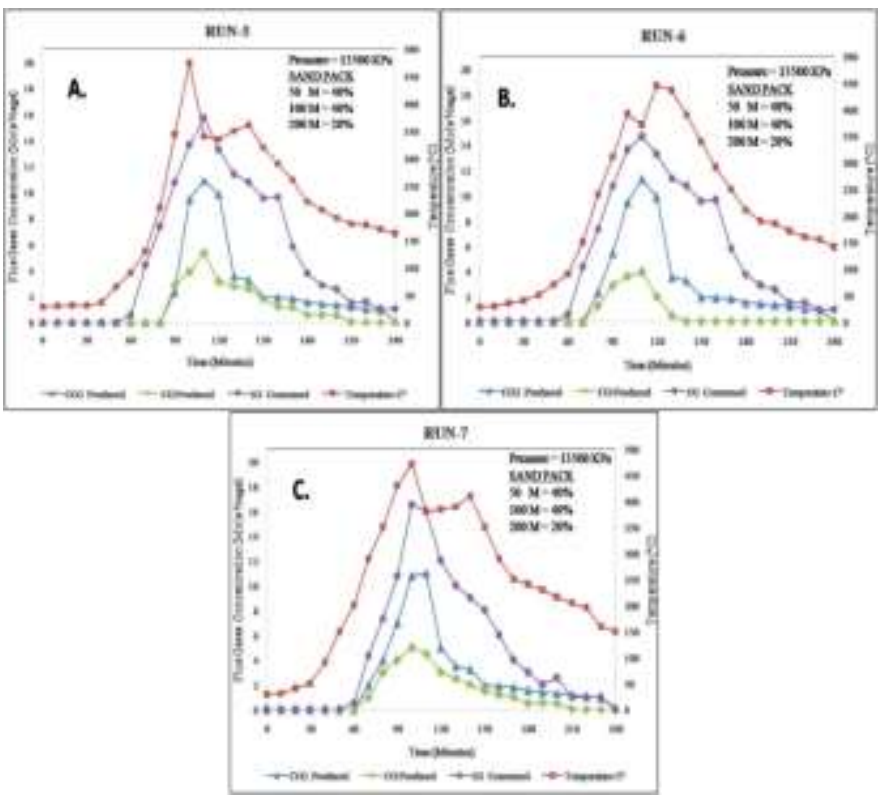

Fig. 5. Flue gases concentration and temperature versus time, A. $15.19 \mathrm{~m}^{3} / \mathrm{m}^{2}$ hr, B. $19.02 \mathrm{~m}^{3} / \mathrm{m}^{2}$-hr, C. $22.78 \mathrm{~m}^{3} / \mathrm{m}^{2}$-hr

TABLE VI

Summary of operating and control parameters by the effect of air flux

\begin{tabular}{|c|c|c|c|c|c|c|}
\hline \multirow[t]{2}{*}{$\begin{array}{l}\text { Run } \\
\text { No. }\end{array}$} & \multicolumn{2}{|c|}{$\begin{array}{l}\text { Injected } \\
\text { Gas } \\
\text { Analysis }\end{array}$} & \multirow{2}{*}{$\begin{array}{c}\text { Operating } \\
\text { Pressure, } \\
\text { KPa }\end{array}$} & \multirow{2}{*}{$\begin{array}{c}\text { Temp: } \\
\text { Condition, } \\
{ }^{\circ} \mathrm{C}\end{array}$} & \multirow{2}{*}{$\begin{array}{l}\text { Flow } \\
\text { Rate, } \\
\text { ml/min }\end{array}$} & \multirow[t]{2}{*}{$\begin{array}{l}\text { Air Flux, } \\
\mathrm{Sm}^{3} / \mathrm{m}^{2}-\mathrm{h}\end{array}$} \\
\hline & $\mathrm{O}_{2}$ & $\mathbf{N}_{2}$ & & & & \\
\hline 5 & 21 & 79 & 13500 & $\begin{array}{c}\text { Non- } \\
\text { Isothermal } \\
\left(5^{\circ} \mathrm{C} / \mathrm{min} .\right)\end{array}$ & 200 & 15.19 \\
\hline
\end{tabular}

Journal of Applied and Emerging Sciences Vol (10), Issue (01)

\begin{tabular}{c|c|c|c|c|c|c}
\hline 6 & 21 & 79 & 13500 & $\begin{array}{c}2^{\text {nd }} \& 3^{\text {rd }} \\
\text { Heater } \\
\text { installed @ } \\
80 \text { v to } \\
\text { maintain } \\
\text { the } \\
\text { reservoir } \\
\text { Temp. } \\
\left(100^{\circ} \mathrm{C}\right)\end{array}$ & 250 & 19.02 \\
\hline 7 & 21 & 79 & 13500 & 22.78 \\
\hline
\end{tabular}

The figures present consumed oxygen, production of $\mathrm{CO}_{2}$ and $\mathrm{CO}$ with different air fluxes. After using different air fluxes15.19, 19.02 and $22.78 \mathrm{~m}^{3} / \mathrm{m}^{2}$-hr, the maximum consumption of oxygen was observed at the air flux of 22.78 $\mathrm{m}^{3} / \mathrm{m}^{2}$-hr. However, at 15.19 and 19.02 air fluxes; the consumption of $\mathrm{O}_{2}$ was slightly lower than the higher fluxes, but at lower flux the oxygen consumed for a longer time as presented in the figures. Increase of air flux resulted in higher rates of oxygen consumption over the temperature range under investigation; consequently, the carbon burned rate increased. The increased rate of cumulative carbon burned effects on the oil production rate. One might expect that increasing rate of flux decreases the distillation and less fuel be deposited, but in contrast to this increased flux appears to have decrease oil displacement from bed and more cumulative carbon is burned $[13,14]$. A possible explanation for this behavior is that at low flux less distillation occurs, and thus lighter residual oil is available for cracking or coking. The effect of different air fluxes on cumulative oil production is shown in figure 6 , while the main results of these experiments are summarized in table 7.

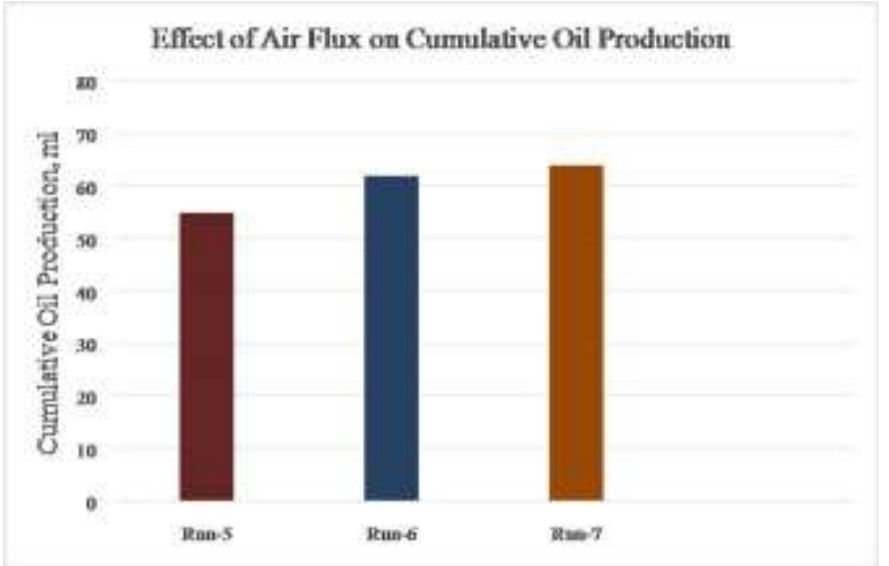

Fig. 6. Cumulative oil production at different air fluxes

TABLE VII

Summary of combustion cell results by the effect of air flux

\begin{tabular}{l|c|c|c}
\hline \multicolumn{1}{c|}{ Parameters } & R-5 & R-6 & R-7 \\
\hline Run Duration, Minutes & 240 & 240 & 240 \\
\hline Cumulative Oil Production, ml & 55 & 62 & 64 \\
\hline Final Oil Recovery, \% OOIP & 68.75 & 77.5 & 80.0 \\
\hline Combustion Front Peak Temp., ${ }^{\circ} \mathrm{C}$ & 475 & 445 & 472 \\
\hline $\begin{array}{l}\text { Max. Concentration of Produced } \mathrm{CO}_{2}, \\
\text { Mole \% }\end{array}$ & 10.8921 & 11.2754 & 11.005 \\
\hline $\begin{array}{l}\text { Max. Concentration of Produced CO, } \\
\text { Mole \% }\end{array}$ & 5.2989 & 3.9285 & 5.019 \\
\hline
\end{tabular}


DOI: https://doi.org/10.36785/BUITEMS.JAES.375

\begin{tabular}{l|c|c|c}
\hline $\begin{array}{l}\text { Max. Concentration of Consumed } \mathrm{O}_{2}, \\
\text { Mole \% }\end{array}$ & 15.7321 & 14.6578 & 16.501 \\
\hline Utilization of $\mathrm{O}_{2}, \%$ & 74.914 & 69.799 & 78.571 \\
\hline
\end{tabular}

\section{Temperature Effect on Heavy Oil Recovery}

Two experimental runs were conducted for determining the temperature effect on oil recovery. The reaction rate was improved by operating the high temperature from two and three heaters, as presented in figure7 (A and B). While all other factors remained constant, which are presented in table 8 . The oxidation reaction took place for a short time by using three electric heaters as compared with two electric heaters. To keep the temperature of $100{ }^{\circ} \mathrm{C}$ for the second zone at reservoir conditions, there were installed two heaters to provide the heat to half of the length of the reactor. Like wise to maintain the reservoir conditions, the temperature above $350{ }^{\circ} \mathrm{C}$ was provided for covering the total length of the reactor, there were installed three electric heaters. The consumption by using three heaters was observed for longer time compared with two electric heaters and the oxygen consumption was $75.4 \%$, as shown in figure 7.

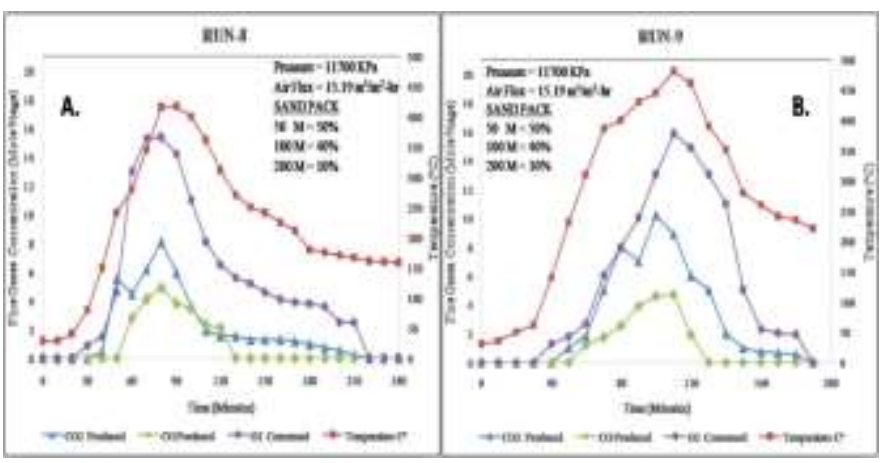

Fig. 7. Flue gases concentration and temperature versus time, A. two heaters, B. three heaters

TABLE VIII

Summary of operating and control parameters by the effect of temperature

\begin{tabular}{c|c|c|c|c|c|c}
\hline $\begin{array}{c}\text { Run } \\
\text { No. }\end{array}$ & $\begin{array}{c}\text { Injected } \\
\text { Gas } \\
\text { Analysis }\end{array}$ & $\begin{array}{c}\text { Operating } \\
\text { Pressure, } \\
\text { KPa }\end{array}$ & $\begin{array}{c}\text { Temp: } \\
\text { Condition, } \\
{ }^{\circ} \mathbf{C}\end{array}$ & $\begin{array}{c}\text { Flow } \\
\text { Rate, } \\
\mathbf{m l} / \mathbf{m i n}\end{array}$ & $\begin{array}{c}\text { Air Flux, } \\
\mathbf{S m}^{3} / \mathbf{m}^{2}-\mathbf{h r}\end{array}$ \\
\cline { 2 - 5 } 8 & $\mathbf{O}_{2}$ & $\mathbf{N}_{2}$ & & $\begin{array}{c}\text { Installed } \\
\text { two heaters } \\
\text { (One for } \\
\text { ignition } \\
\text { and 2nd } \\
\text { heater to } \\
\text { maintain } \\
\text { the } \\
\text { reservoir } \\
\text { Temp. }\end{array}$ & 200 & 15.19 \\
\hline
\end{tabular}

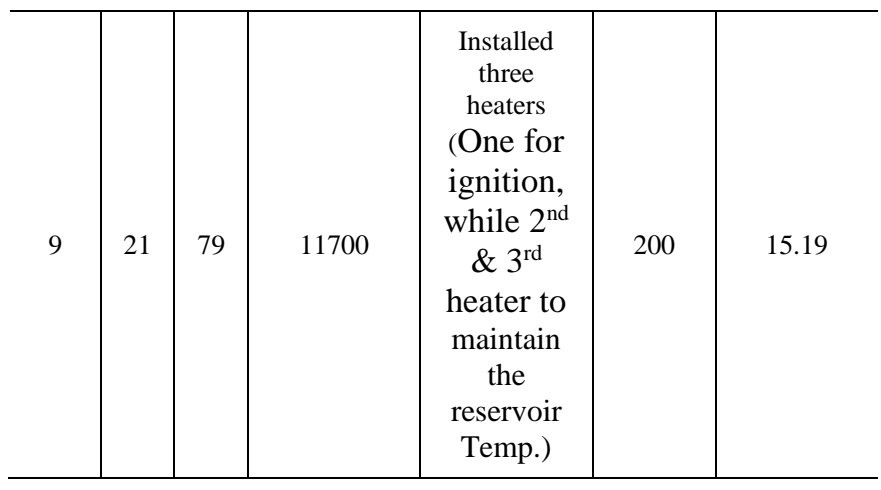

For better analysis, different temperatures were drawn for oxygen consumption with function of time as an abscissa. The mentioned figure 7 shows the consumption of oxygen at disparate heat input. From the experimental results obtained by heat input effect, it was determined that the combustion rate was enhanced when the number of heaters was increased. The composition of effluent gases $\left(\mathrm{O}_{2}, \mathrm{CO}_{2}\right.$ and $\left.\mathrm{CO}\right)$ achieved by the combustion reaction is withdrawn from the plots as presented in the figures. Figure 8 shows the effect of heat input on final recovery of crude oil, while table 9 presents the summary of flue gas results.

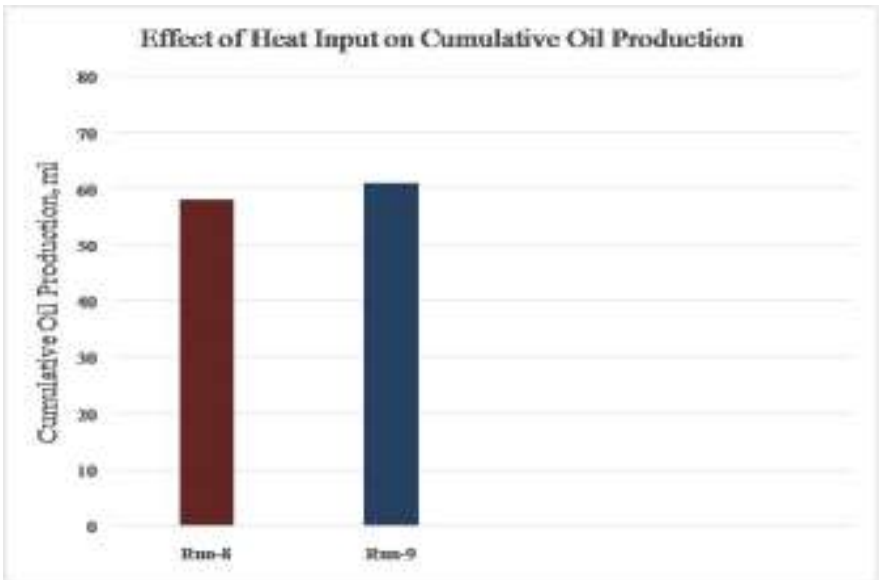

Fig. 8. Cumulative oil production at different heat inputs

TABLE IX

Summary of combustion cell results by the effect of temperature

\begin{tabular}{l|c|c}
\multicolumn{1}{c|}{ Parameters } & R-8 & R-9 \\
\hline Run Duration, Minutes & 240 & 190 \\
\hline Cumulative Oil Production, ml & 58 & 61 \\
\hline Final Oil Recovery, \% OOIP & 72.5 & 76.25 \\
\hline Combustion Front Peak Temp., ${ }^{\circ} \mathrm{C}$ & 416 & 480 \\
\hline Max. Concentration of Produced $\mathrm{CO}_{2}$, Mole \% & 8.0891 & 10.20 \\
\hline Max. Concentration of Produced $\mathrm{CO}_{1}$ Mole \% & 4.9204 & 4.70 \\
\hline Max. Concentration of Consumed $\mathrm{O}_{2}$, Mole $\%$ & 15.3274 & 15.834 \\
\hline Utilization of $\mathrm{O}_{2}, \%$ & 72.987 & 75.40 \\
\hline
\end{tabular}




\section{DOI: https://doi.org/10.36785/BUITEMS.JAES.375}

\section{Porous Media Effect on Heavy Oil Recovery}

Various sets of non-isothermal experiments performed under similar operating conditions with different sand pack properties. On the basis of different sizes of sand matrix, the profiles of flue gas analysis were studied. During the experiments, short amount of oxygen was consumed at lower than $100{ }^{\circ} \mathrm{C}$ temperature and no production of carbon oxides was observed. After reaching at temperature above $200{ }^{\circ} \mathrm{C}$, greater amount of $\mathrm{O}_{2}$ was consumed with production of $\mathrm{CO}_{2}$, as presented in figure 9 (A, B, C, and D). A summary of these porous media with the experimental conditions employed for each run is given in table 10 and 11 . The behavior of heavy oil in unconsolidated rock formation with low permeability showed usual behavior. For better analysis, different sand packs were drawn for oxygen consumption with function of time as an abscissa. The figures present consumed oxygen and production of carbon oxides. The appearance of high temperature oxidation (HTO) reactions in these experiments was credited to the increasing of bed thickness. Decreasing the mesh size of the sand particles with low permeability provided better availability of oxygen to the crude oil and thus, preferred the existence of HTO reactions. Higher production rate of effluent gases was the result of HTO providing more fuel to be burned. The broadening of the HTO peak was also attributed to the above effect.

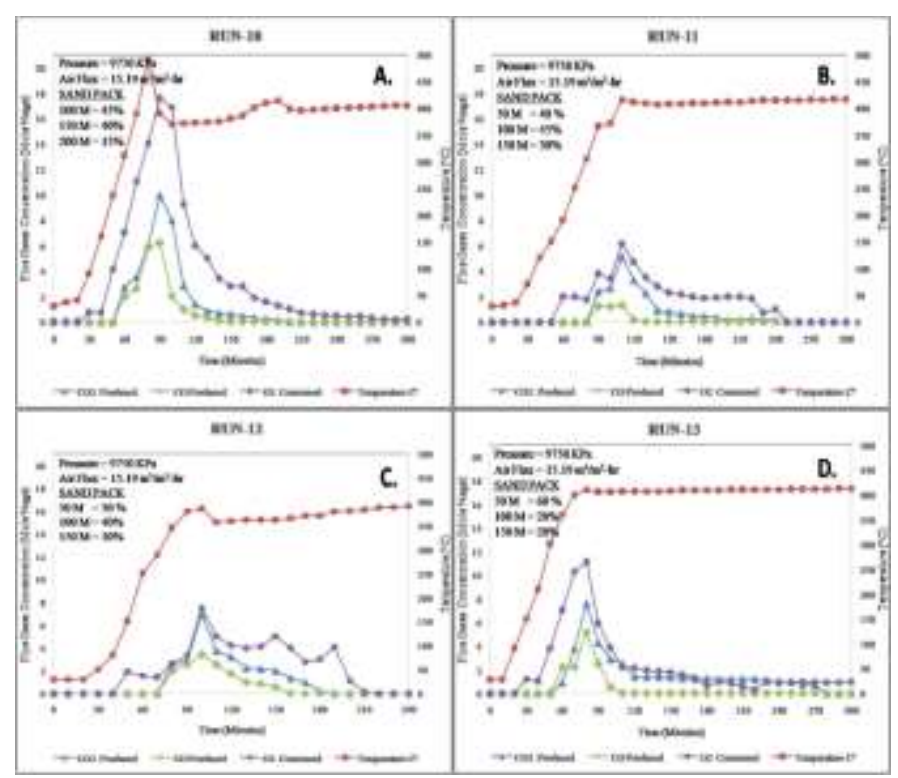

Fig. 9. Flue gases concentration and temperature versus time, A. at sand mix1, B. at sand mix-2, C. at sand mix-3, D. at sand mix-4

TABLE X

Summary of sand pack parameters by the effect of porous media

\begin{tabular}{|c|c|c|c|c|c|c|c|c|}
\hline \multirow{2}{*}{$\begin{array}{l}\text { Run } \\
\text { No. }\end{array}$} & \multicolumn{4}{|c|}{$\begin{array}{l}\text { Percent by Weight of } \\
\text { Different Meshes }\end{array}$} & \multirow{2}{*}{$\begin{array}{c}\text { Total } \\
\text { Wt., } \\
\%\end{array}$} & \multirow{2}{*}{$\begin{array}{c}\text { Oil } \\
\text { Gravity, } \\
{ }^{\circ} \text { API }\end{array}$} & \multirow{2}{*}{$\begin{array}{c}\text { Oil } \\
\text { Vol, } \\
\text { ml }\end{array}$} & \multirow{2}{*}{$\begin{array}{c}\text { Oil } \\
\text { Wt., } \\
\%\end{array}$} \\
\hline & 50 & 100 & 150 & 200 & & & & \\
\hline 10 & - & 45 & 40 & 15 & 100 & 12.59 & 80 & 24.5 \\
\hline
\end{tabular}

Journal of Applied and Emerging Sciences Vol (10), Issue (01)

\begin{tabular}{c|c|c|c|c|c|c|c|c}
\hline 11 & 40 & 40 & 30 & - & 100 & 12.59 & 80 & 24.5 \\
\hline 12 & 50 & 40 & 10 & - & 100 & 12.59 & 80 & 24.5 \\
\hline 13 & 60 & 20 & 20 & - & 100 & 12.59 & 80 & 24.5 \\
\hline
\end{tabular}

TABLE XI

Summary of operating and control parameters by the effect of porous media

\begin{tabular}{|c|c|c|c|c|c|c|}
\hline \multirow{2}{*}{$\begin{array}{l}\text { Run } \\
\text { No. }\end{array}$} & \multicolumn{2}{|c|}{$\begin{array}{l}\text { Injected } \\
\text { Gas } \\
\text { Analysis }\end{array}$} & \multirow{2}{*}{$\begin{array}{c}\text { Operating } \\
\text { Pressure, } \\
\text { KPa }\end{array}$} & \multirow{2}{*}{$\begin{array}{c}\text { Temp: } \\
\text { Condition, } \\
{ }^{\circ} \mathrm{C}\end{array}$} & \multirow{2}{*}{$\begin{array}{l}\text { Flow } \\
\text { rate, } \\
\mathrm{ml} / \mathrm{min}\end{array}$} & \multirow{2}{*}{$\begin{array}{l}\text { Air Flux, } \\
\mathrm{Sm}^{3} / \mathbf{m}^{2}-\mathrm{hr}\end{array}$} \\
\hline & $\mathrm{O}_{2}$ & $\mathbf{N}_{2}$ & & & & \\
\hline 10 & 21 & 79 & 9750 & \multirow{4}{*}{$\begin{array}{l}\text { Non Iso- } \\
\text { thermal } \\
5{ }^{\circ} \mathrm{C} / \mathrm{min}\end{array}$} & 200 & 15.19 \\
\hline 11 & 21 & 79 & 9750 & & 200 & 15.19 \\
\hline 12 & 21 & 79 & 9750 & & 200 & 15.19 \\
\hline 13 & 21 & 79 & 9750 & & 200 & 15.19 \\
\hline
\end{tabular}

The experimental results revealed that the oil displacement and distillation could be one of the main and important mechanisms of fuel deposition. At low permeability, the reaction between light components and $\mathrm{O}_{2}$ may be high, hence producing $\mathrm{CO}$ and $\mathrm{CO}_{2}$. As $\mathrm{CO}$ could be the main source for the production of $\mathrm{CO}_{2}$; therefore, with increased combustion time, $\mathrm{CO}$ reacts with $\mathrm{O}_{2}$ species to produce $\mathrm{CO}_{2}$. The higher amount of the $\mathrm{CO}$ may indicate the deficiency of $\mathrm{O}_{2}$ to the reaction front, resulted incomplete combustion [15]. The distillation effect at high pressure may be low, therefore; more under saturated hydrocarbon molecules are produced to react with oxygen than with the sand pack. This indicates an incomplete oxidation reaction, which may be attributed to the low operating temperature used with the increased combustion time [16]. Figure 10 shows the effect of different sand pack sizes on final recovery of heavy crude oil, and table 12 presents the summary of flue gas results.

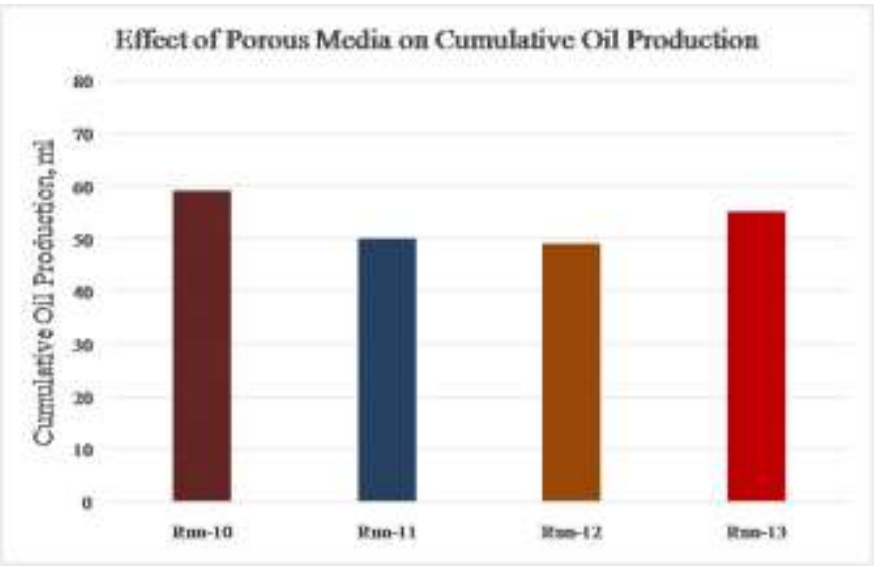

Fig. 10. Cumulative oil production at different sand packs

TABLE XII 
Summary of combustion cell results by the effect of porous

\begin{tabular}{|c|c|c|c|c|}
\hline Parameters & R-10 & R-11 & R-12 & R-13 \\
\hline Run Duration, Minutes & 300 & 300 & 240 & 300 \\
\hline $\begin{array}{l}\text { Cumulative Oil } \\
\text { Production, ml }\end{array}$ & 59 & 50 & 49 & 55 \\
\hline $\begin{array}{l}\text { Final Oil Recovery, } \\
\% \text { OOIP }\end{array}$ & 73.75 & 62.5 & 61.25 & 68.75 \\
\hline $\begin{array}{l}\text { Combustion Front } \\
\text { Peak Temp., }{ }^{\circ} \mathrm{C}\end{array}$ & 489 & 415.4 & 385 & 410 \\
\hline $\begin{array}{l}\text { Max. Concentration of } \\
\text { Produced } \mathrm{CO}_{2} \text {, Mole } \\
\%\end{array}$ & 9.9354 & 5.1172 & 6.8971 & 7.60 \\
\hline $\begin{array}{l}\text { Max. Concentration of } \\
\text { Produced CO, Mole \% }\end{array}$ & 6.1932 & 1.1993 & 3.3971 & 5.1241 \\
\hline $\begin{array}{l}\text { Max. Concentration of } \\
\text { Consumed } \mathrm{O}_{2} \text {, Mole } \%\end{array}$ & 17.564 & 6.1265 & 7.5012 & 11.1 \\
\hline Utilization of $\mathrm{O}_{2}, \%$ & 83.6380 & 29.1738 & 35.720 & 52.8571 \\
\hline
\end{tabular}

\section{CONCLUSION}

- During the air injection in sand pack impregnated with heavy crude oil, observed a series of different oxidation reactions (low temperature oxidation reactions, fuel deposition reactions and high temperature oxidation reactions). The results obtained from the experimental analysis conclude that:

- The process is very dependent on operating conditions employed, as oxygen consumption rate was very dependent on air flux. The temperature difference also shows great effect on the high temperature oxidation. The pressure and porous media also have great impact on the combustion behavior. However, less consumption of oxygen was observed in large values of these four parameters due to the reason of small number of light components present in the reservoir.

- It investigated that in porous media the burning rate of carbon in crude oil was dependent over the carbon concentration, air injection pressure and combustion temperature. At high temperature, the oxidation reaction process was very effective in terms of produced carbon oxides with an average percentage of $9.5 \% \mathrm{CO}_{2}, 5.5 \% \mathrm{CO}$ in flue gases. The oxygen with reservoir heavy crude forms reaction at high temperature oxidation $\left(>400{ }^{\circ} \mathrm{C}\right)$.

- The experimental results reveal that the average maximum peak temperature was $440{ }^{\circ} \mathrm{C}$, while a small portion of the fuel available in the reservoir reacted below $350{ }^{\circ} \mathrm{C}$. Increase of air flux from 15.19 to 22.78 $\mathrm{m}^{3} / \mathrm{m}^{2}$-hr resulted in slightly increasing rates of oxygen consumption over the temperature range under investigation.

- It was observed that by increasing pressure and heat input, oxidation reaction rate increases, also rate of air injection must be limited to prevent excessive loss of heat towards the combustion zone. Thus, from the analysis of flue gases, oil displacement was observed. The incremental oil recovery achieved under high temperature oxidation (HTO) conditions, varies between $56 \%-80 \%$. Therefore, the economics of in-situ combustion for heavy crude oils can be augmented by using the effect of applied parameters in real reservoir combustions.

\section{REFERENCES}

J. Barillas, T. D. Júnior, and W. Mata, "Improved oil recovery process for heavy oil: a review," Brazilian journal of Petroleum and gás, vol. 2, 2008.

V. Alvarado and E. Manrique, "Enhanced oil recovery: an update review," Energies, vol. 3, pp. 1529-1575, 2010.

Y. Wu, A. Mahmoudkhani, P. Watson, T. Fenderson, H. S. Kolla, and M. Nair, "A non-thermal surfactantpolymer based technology for enhanced heavy oil recovery in oil sand and ultra shallow reservoirs," in SPE Heavy Oil Conference Canada, 2012.

[4] M. Ursenbach, R. Moore, and S. Mehta, "Air injection in heavy oil reservoirs-a process whose time has come (again)," Journal of Canadian Petroleum Technology, vol. 49, pp. 48-54, 2010.

[5] L. Zhong, D. Yu, Y. Gong, P. Wang, L. Zhang, and C. Liu, "Feasibility Study of the In-Situ Combustion in Shallow, Thin, and Multi-Layered Heavy Oil Reservoir," in International Thermal Operations and Heavy Oil Symposium, 2008.

[6] D. Gutierrez, F. Skoreyko, R. Moore, S. Mehta, and M. Ursenbach, "The challenge of predicting field performance of air injection projects based on laboratory and numerical modelling," Journal of Canadian Petroleum Technology, vol. 48, pp. 23-33, 2009.

[7] A. H. Tunio, "To Investigate the Use of Air Injection to Improve Oil Recovery from Light Oil Reservoirs," MEHRAN UNIVERSITY OF ENGINEERING \& TECHNOLOGY JAMSHORO, 2008.

[8] H. Al-Saffar, D. Price, A. Soufi, and R. Hughes, "Distinguishing between overlapping low temperature and high temperature oxidation data obtained from a pressurised flow reactor system using consolidated core material," Fuel, vol. 79, pp. 723-732, 2000. 


\section{DOI: https://doi.org/10.36785/BUITEMS.JAES.375}

[9] O. Cazarez-candia and J. Cruz-Hernandez, "Effect of pressure and air flow rate on in-situ combustion experiments of heavy oil," in SPE Latin America and Caribbean Petroleum Engineering Conference, 2012.

[10] J. Rodriguez and D. Mamora, "Analytical model of the combustion zone in oxygen-enriched in situ combustion tube experiments," in Canadian International Petroleum Conference, 2005.

[11] M. Kumar and A. Garon, "A method for performance prediction and comparison of oxygen and air fireflooding," in SPE/DOE symposium on enhanced oil recovery. 5, 1986, pp. 515-528.

[12] A. Mendoza, H. Perozo, D. A. Oliveros, and N. Reyes, "Study for Improving the In-Situ Combustion of Venezuela Extra-Heavy Crude Oil Using Unconventional Additive," in SPE Latin American and Caribbean Petroleum Engineering Conference, 2010.

[13] A. M. Chicuta and O. V. Trevisan, "Experimental study on in-situ combustion of a Brazilian heavy oil," in Latin American and Caribbean Petroleum Engineering Conference, 2009.

[14] M. Greaves, A. Wilson, M. Al-Honi, and A. Lockett, "Improved recovery of light/medium heavy oils in heterogeneous reservoirs using air injection/insitu combustion (ISC)," in SPE Western Regional Meeting, 1996.

[15] D. Marjerrison and M. Fassihi, "A procedure for scaling heavy-oil combustion tube results to a field model," in SPE/DOE Enhanced Oil Recovery Symposium, 1992.

[16] R. Prasad and J. Slater, "High-Pressure Combustion Tube Tests," in SPE Enhanced Oil Recovery Symposium, 1986.

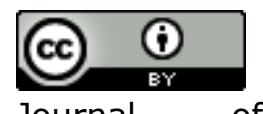

of Applied and Emerging Sciences by BUITEMS is licensed under a Creative Commons Attribution 4.0 International License. 